\title{
SELECTED PROBLEMS OF THE VALUE APPRAISAL OF REAL ESTATE BUILT CONTRARY TO CONSTRUCTION LAW - PART II
}

\author{
Maria Zbylut-Górska, Adam Górski
}

\section{Summary}

The scope of the examination of the actual condition, and the examination of the legal status of real estate property has long raised practical doubts and dilemmas. In particular, the issue of the expert's obligation to take into account irregularities in construction proceedings raises a number of reservations.

In the first part of the article, the concept of illegal construction works (performed without a building permit) had been presented; the duties of the appraiser provided for in the Real Estate Management Act were listed; the consequences of illegal construction works performed without a building permit, and other defects in the construction process were described, as well as difficulties in determining whether a given object had in fact been illegally constructed. Examples of decisions and permits issued in the construction process and their significance for the property appraiser were discussed.

The second part of the article analyses the impact of the building permit on the price of the real estate property and discusses the scope of the obligation for the property appraiser to examine the compliance of the valued property with building regulations. Examples of bank's requirements for property appraisers are indicated, and the problem of the practical significance of clauses included in real estate appraisal reports are presented. The discussion of all the above issues concludes with a summary.

As a rule, a real estate property appraiser is not a person authorized to assess whether a given object, in whole or in part, has been built or is being used in accordance with building regulations. The appraiser, due to the statutory duty to exercise special diligence appropriate to the professional nature of his or her activities, is required to collect and use all necessary and available data on the given real estate property. If a discrepancy is found in the analysed documentation, the appraiser should mention it in the report. The appraiser is neither entitled nor obliged to determine the causes of the discrepancies. The indicated circumstances justify the inclusion in the report a clause that the valuation of the property in question may change due to discrepancies revealed, or proceedings being conducted. Failure to provide relevant information and reservations may justify the expert's liability under the applicable provisions of the Civil Code.

\section{Keywords}

real estate appraisal $\bullet$ construction law $\bullet$ illegal construction works (without a building permit) - building permit 


\section{Introduction}

In the first part of the article, the concept of illegal construction works (performed without a building permit) had been presented; the duties of the appraiser provided for in the Real Estate Management Act were listed; the consequences of illegal construction works performed without a building permit, and other defects in the construction process were described, as well as difficulties in determining whether a given object had in fact been illegally constructed. Examples of decisions and permits issued in the construction process and their significance for the property appraiser were discussed.

The second part of the article analyses the impact of the building permit on the price of the real estate property and discusses the scope of the obligation for the property appraiser to examine the compliance of the valued property with building regulations. Examples of bank's requirements for property appraisers will be indicated, and the problem of the practical significance of clauses included in real estate appraisal reports will be presented. The discussion of all the above issues shall conclude with a summary.

\section{Analysis of the building permit's impact on the price of the real estate property - introduction}

The real estate market offer includes both real estate properties with a building permit, and those without a permit. Having a building permit allows the investor to start construction immediately, but on the other hand, it forces a compromise consisting in having to adapt to the vision of the building embraced by the previous owner. The building permit determines that the necessary approvals had been obtained for the real estate property, and the necessary permits had been granted (e.g. water law permit, permit for the location of the exit, etc.). In some cases, it will be possible to use the existing approvals and permits during any proceedings aimed at changing the approved construction project (see Article 36a [1]), for instance when changing the body of a building while maintaining the existing location of the exit over the drainage ditch. The use of some documentation will undoubtedly help reduce costs and save time in the investment design phase. The fact of having a building permit is undoubtedly an important factor from the point of view of a real estate property appraiser. The Real Estate Management Act explicitly indicates a building permit as a source of real estate data, see: Article 155 [2]. Having a building permit is treated as an additional advantage of the real estate property. For practical reasons, however, it seems necessary to attempt to examine the impact of the building permit on the price of the property. Performing such an analysis is important in particular in the case of a defective building permit, i.e. one that may produce grounds for its revocation by resumption of proceedings, or by annulment. As was emphasized, the appraiser cannot be required to verify the final building permit decision, because such an action would contradict the principle expressed in Article 16 [3], i.e. the presumption of correctness of final administrative decisions. However, the obligation to exercise special diligence appropriate to the professional nature of the real estate property appraiser's activities requires that information be obtained as to whether any pertinent procedures are being carried out to repeal the final building permit decision. 
In view of the above, in order to attempt to examine the impact of the building permit on the price of real estate, an analysis of transaction prices of undeveloped real estate properties without a building permit was carried out, and these prices were compared with real estate properties having a building permit. Based on the data from notarial deeds available in the Kraków Municipal Office, real estate properties located in the city of Kraków with an area ranging between $700 \mathrm{~m}^{2}$ and $2000 \mathrm{~m}^{2}$ were selected. In addition, each of the analysed properties was covered by PZP (spatial development plan) or development conditions decisions were issued for it, in which these properties were intended for single-family housing $(\mathrm{MN})$. The analysis was based on purchase and sale transactions concluded in 2016-2017 in the city of Kraków. Before proceeding with the analysis of real estate prices, a time trend was set in order to determine whether real estate prices changed in the years under consideration. Based on the determined trend lines, for both real estate properties, and for building permits, it was considered that the passage of time had no material effect on the change in real estate property prices. Therefore, no adjustment was necessary.

The analysis was conducted based on 90 purchase and sale transactions of undeveloped properties, similar in terms of area and use (designation), and located in Kraków in the same sections of the respective districts. A valid building permit has been issued for 26 of the selected properties. Due to the fact that in most cases, providing only the average price may be misleading, as it does not properly reflect the characteristics of the market, see for instance [4], [5]. In this article, we have also calculated measures of location, dispersion, asymmetry, and concentration of real estate prices.

\section{Analysis of real estate properties without a building permit in the city of Kraków}

From January 2016 to December 2017, 64 purchase and sale transactions of real estate without a building permit selected according to the above criteria were concluded in Kraków. Of the transactions analysed, the majority (31 transactions) were recorded in the Podgórze district, followed by 18 real estate transactions recorded in the Krowodrza district. 15 transactions were concluded in the Nowa Huta district, while no transactions meeting the given criteria were recorded in the Sródmieście district. The average property price from this database is PLN 294.43, with a standard deviation of the average property price at PLN 28.24. The standard deviation of a single property price is PLN 225.89 and the coefficient of variation is at the level of $76.7 \%$, which signifies a fairly large diversity of data in relation to the mean value. The prices for these real estate properties range from $29.94 \mathrm{PLN} / \mathrm{m}^{2}$ to $1200.00 \mathrm{PLN} / \mathrm{m}^{2}$. Measure of the asymmetry (skewness) at 1.65 indicates right-tailed distribution of data, while a high, positive kurtosis value of 3.63 indicates greater slenderness of the data distribution compared to the normal distribution. Due to the significant dispersion of data, quartiles have been determined, which are more suitable for describing the databases with high dispersion [4] (for instance). The second quartile (median) is PLN 231.42; with half of the prices in the entire set remaining below this value, while three-quarters of 
the prices in the set are below the third quartile, which is PLN 366.43. The distribution series of relative frequencies expressed as a percentage, for real estate with an area of $700-2000 \mathrm{~m}^{2}$ and without a building permit is presented in Table 1.

Table 1. Relative frequency distribution for real estate properties without a building permit

\begin{tabular}{|c|c|}
\hline Class intervals PLN/ $\mathbf{m}^{2}$ & Relative frequency (\%) \\
\hline$(-\infty-29.9]$ & 0 \\
\hline$(29.9-197.4]$ & 37.50 \\
\hline$(197.4-364.9]$ & 35.94 \\
\hline$(364.9-532.4]$ & 14.06 \\
\hline$(532.4-699.9]$ & 6.25 \\
\hline$(699.9-867.4]$ & 3.13 \\
\hline$(867.4-1034.9]$ & 1.56 \\
\hline$(1034.9-1202.4]$ & 1.56 \\
\hline Over 1202.4 & 0 \\
\hline Total & 100 \\
\hline
\end{tabular}

In order to better illustrate the results, and especially the measures of dispersion, Figure 1 presents a histogram showing how many properties from the analysed database remain, at the same time, within a specific price range.

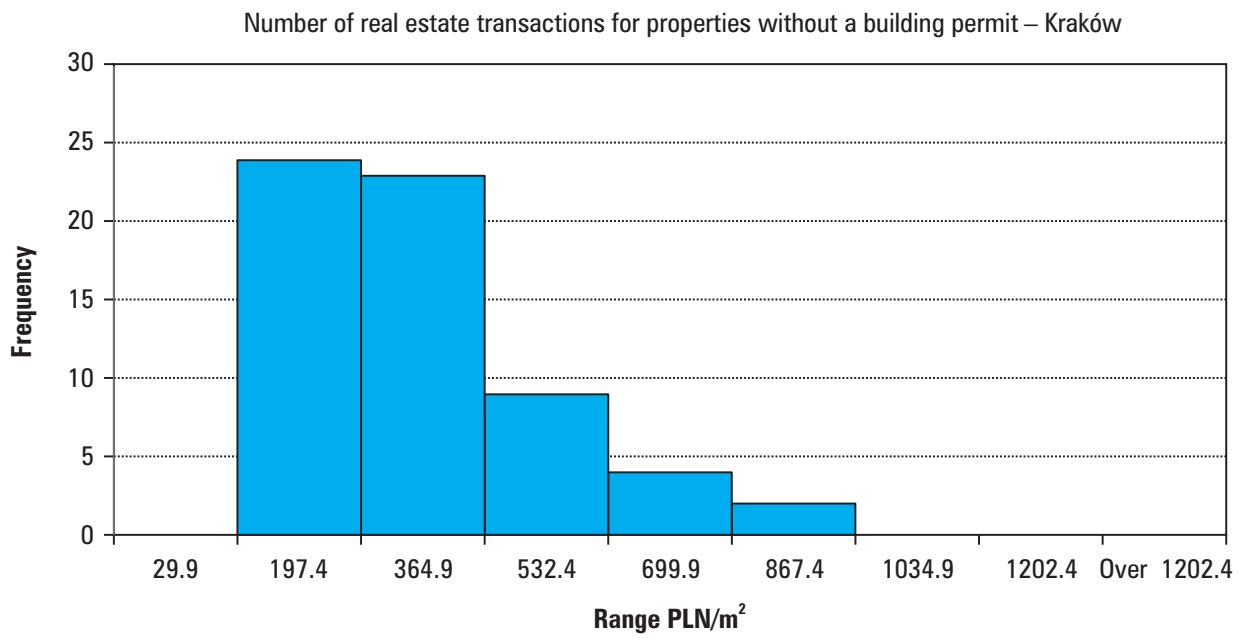

Source: Authors' own study

Fig. 1. Price distribution of real estate properties without a building permit 


\section{Analysis of real estate properties with a building permit in the city of Kraków}

As mentioned above, real estate properties with a building permit constitute less than $30 \%$ of all real estate properties sold that meet the specified criteria. Over $50 \%$ of the transactions were recorded in the Podgórze district; seven transactions were concluded in the Krowodrza district; and five in the Nowa Huta district. The analysis showed that the average price of real estate with a building permit is PLN 392.48 with a standard deviation of the average real estate price at PLN 66.75. The high value of standard deviation of a single property price - amounting to PLN 340.34 - and thus also the high value of the coefficient of variation at $86.7 \%$ indicate a significant dispersion of data relative to the mean value. For properties with a building permit, the price ranges from PLN 97.64 to PLN 1535.63, therefore, the range is PLN 1437.99. In order to examine how the data in the examined set are dispersed, as in the previous analysis, skewness and kurtosis were determined. Similarly to the previous case, these values are fairly high, with skewness at 2.21 and kurtosis at 5.18 . They testify to the right-tailed distribution, more slender than normal, as shown in Figure 2. Again, in the case of the examined database, due to its large dispersion, the quartiles were determined. The median for real estate with a building permit is PLN 305.12, while the third quartile is PLN 456.29. Thus, more than three quarters of all the surveyed real estate prices do not exceed $456 \mathrm{PLN} / \mathrm{m}^{2}$.

In order to illustrate the evolution of real estate prices in individual price ranges, a distribution series of relative frequencies expressed as percentage (Table 2) has been created for real estate properties with an area of $700-2000 \mathrm{~m}^{2}$, with building permits.

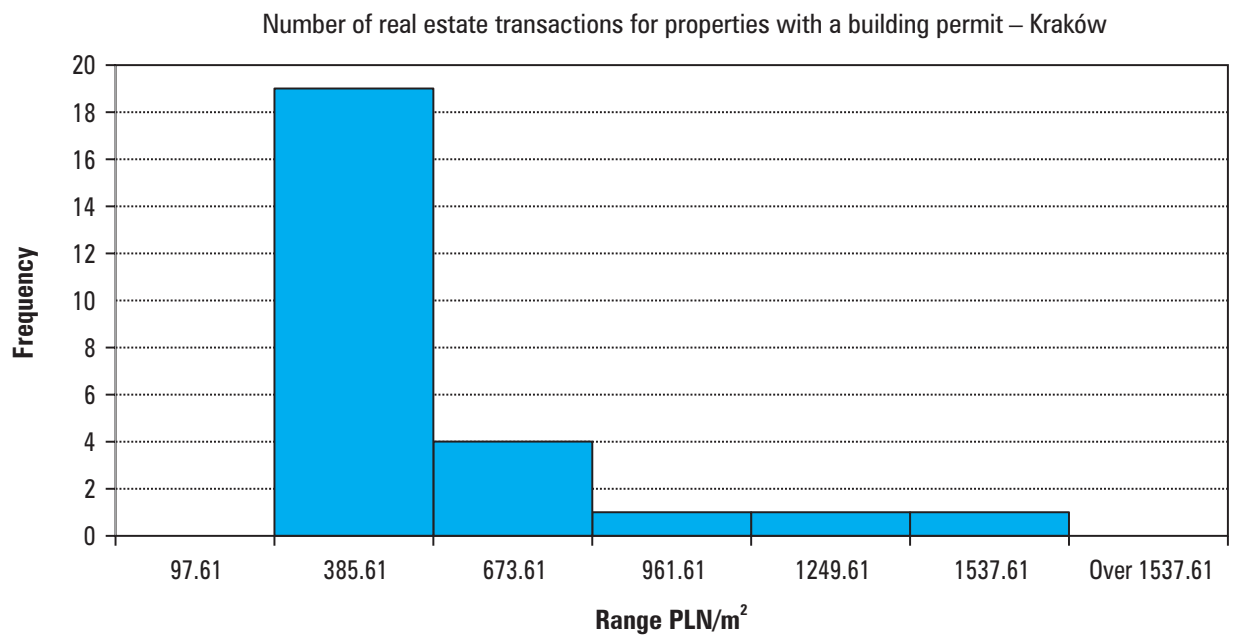

Source: Authors' own study

Fig. 2. Price distribution of real estate properties with a building permit 
Table 2. Relative frequency distribution for real estate properties with a building permit

\begin{tabular}{|c|c|}
\hline Class intervals PLN $/ \mathbf{m}^{2}$ & Relative frequency (\%) \\
\hline$(-\infty-97.61]$ & 0 \\
\hline$(97.61-385.61]$ & 73.08 \\
\hline$(385.61-673.61]$ & 15.38 \\
\hline$(673.61-961.61]$ & 3.85 \\
\hline$(961.61-1249.61]$ & 3.85 \\
\hline$(1249.61-1537.61]$ & 3.85 \\
\hline Over 1537.61 & 0 \\
\hline Total & 100 \\
\hline
\end{tabular}

\section{Presentation of research results}

In order to attempt an assessment of the building permit's impact on the price of real estate property, the results obtained in both analyses were compared. Due to the large dispersion of data, median constitutes a better measure of comparison, because in both sets there are few values that differ significantly from the others, thus unnecessarily inflating the mean value. The compared values are presented in Table 3.

Table 3. Comparison between the values of the second and third quartiles and the price range of real estate properties with and without building permit

\begin{tabular}{|l|c|c|}
\hline & $\begin{array}{c}\text { Without a building } \\
\text { permit Kraków }\end{array}$ & $\begin{array}{c}\text { With a building } \\
\text { permit Kraków }\end{array}$ \\
\hline Median & PLN 231.42 & PLN 305.12 \\
\hline Third quartile & PLN 366.43 & PLN 456.29 \\
\hline $\begin{array}{l}\text { Range (difference between the maximum and } \\
\text { minimum price) }\end{array}$ & PLN 1170.06 & PLN 1437.99 \\
\hline
\end{tabular}

Based on the compared values, it can be stated that price of real estate possessing a building permit is higher by about PLN $70 / \mathrm{m}^{2}$. Having said that, it is difficult to state unequivocally that it is only the building permit that has an impact on this value, as there are many other features other than the area size and functional designation of the real estate property, and these have also been included in the database. The location of the property undoubtedly has a significant impact. Therefore, due to the highest availability of data, an additional analysis was carried out for real estate properties located in the Podgórze district only. It should be emphasized that real estate properties - both with and without a building permit - were selected from the same areas 
of the analysed district. A similar analysis was again carried out, as for the previously analysed real estate properties. As it was emphasized earlier, 31 real estate properties without building permits were sold in the Podgórze district. The mean price of these properties was PLN 261.06, with a standard deviation of the mean property price at PLN 15.85, whereas the standard deviation of a single property price is PLN 88.25 and is slightly over $30 \%$ of the mean value, which indicates that the analysed property prices are more concentrated around the average price. This was not the case in the case of real estate properties considered in the whole of Kraków city. The median for the analysed prices is PLN 273.76 while the third quartile is PLN 354.39. The price range is also much smaller, because the minimum price is $107.91 \mathrm{PLN}$ and the maximum price is 431.01 PLN. Additionally, parameters such as the skewness coefficient and the kurtosis coefficient -0.21 (skewness) and -0.89 (kurtosis), respectively - indicate that the price distribution is more similar to the normal distribution than in previous analyses, which is further confirmed by the histogram presented in Figure 3.

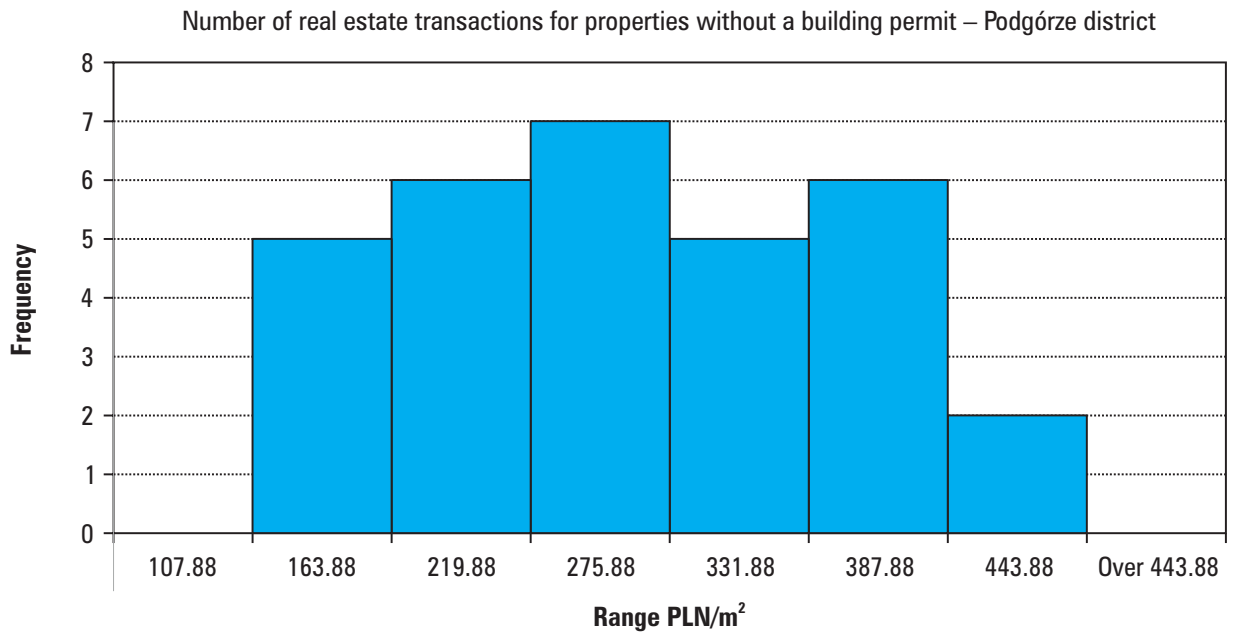

Source: Authors' own study

Fig. 3. Price distribution of real estate properties without a building permit, located within Podgórze district

The situation is similar for 14 properties in the Podgórze district that have a building permit. The mean price of these properties is PLN 278.26 with the standard deviation of the mean property price at PLN 28.58. The standard deviation of a single property price is PLN 106.95, therefore, prices are slightly less concentrated around the mean than for real estate properties located in this district and lacking building permits, however, they are not as dispersed as in the case of the analysis carried out for the whole of Krakow. The smaller dispersion of data is also evidenced by the values for skewness (0.33) and kurtosis (-0.40), as well as the difference between the maximum 
price (PLN 497.87) and the minimum price (PLN 122.52), amounting to PLN 375.35. The distribution of prices is shown in Figure 4.

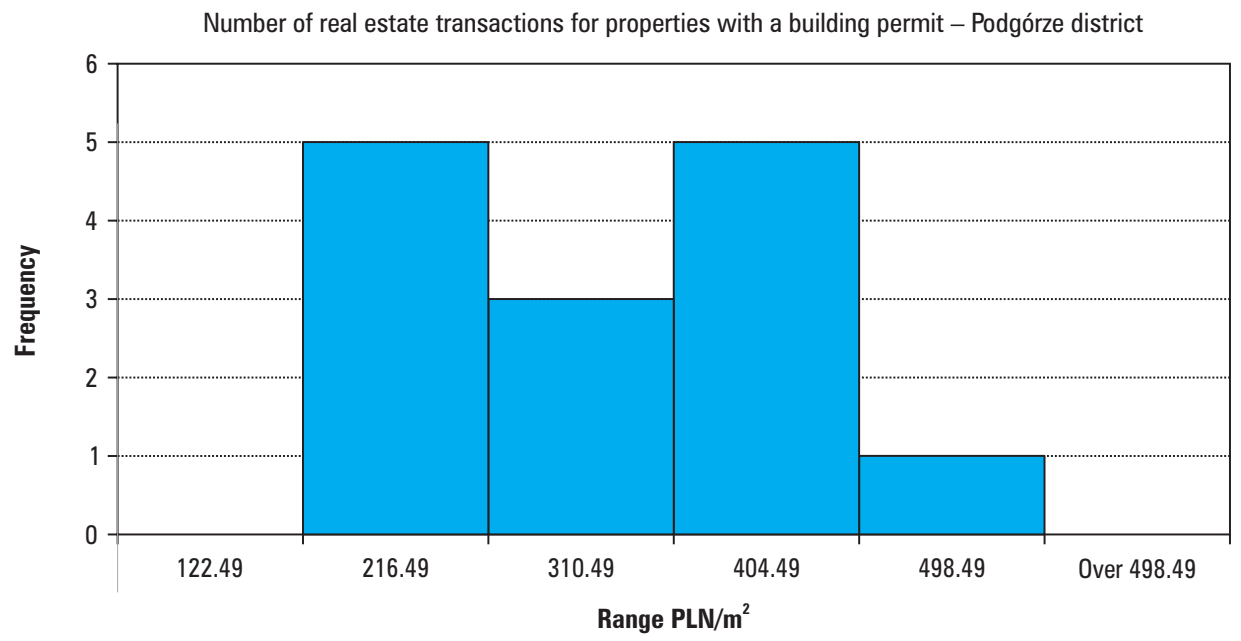

Source: Authors' own study

Fig. 4. Price distribution of real estate properties with a building permit, located within Podgórze district

When comparing the results obtained for properties with and without a building permit for the Podgórze district, it can be concluded that with more precisely defined location, the impact of the building permit decreased, and amounted to less than PLN 20 when we compare mean values, and about PLN 36 when we compare the medians, which has been demonstrated in Table 3. Due to the smaller dispersion of data for the Podgórze district, the arithmetic mean is a more reliable comparative value, however, to maintain consistency with previous considerations, the median value for both analyses is also provided.

Table 4. Comparison of mean and median values for real estate properties with and without building permit, located within Podgórze district

\begin{tabular}{|l|c|c|}
\hline & Without building permit - Podgórze district & With building permit - Podgórze district \\
\hline Mean & PLN 261.06 & PLN 279.25 \\
\hline Median & PLN 237.45 & PLN 273.76 \\
\hline
\end{tabular}

Having conducted the analysis, it appears that the building permit does not significantly affect the price of the land. When analysing the data for the whole of Kraków, 
the difference of PLN 100 per $1 \mathrm{~m}^{2}$ seems significant, however, after narrowing the consideration to the area of the district, it decreases to almost $1 / 5$ of the indicated value. Thus, the price difference at the level of less than PLN 20 can hardly be considered a significant difference.

Having said that, the above statement does not exclude the liability of the appraiser in the case of the valuation of real estate property with a defective building permit, for which proceedings were instituted regarding the revocation of such permit, if he or she fails to make a proper mention in the report. The appraiser will be liable due to the lack of special diligence appropriate to the professional nature of the activity. The scope of this liability will depend on whether the investor has suffered damage and in what amount.

\section{Scope of the obligation to examine the compliance of the valued property with building regulations}

When addressing the issue of the scope of the obligation to examine the compliance of the valued property with building regulations, it should be noted that the agreement between the contracting party (the client) and the expert appraiser is also relevant in this matter. The scope of the appraisal report is agreed in each case with the client. Indication of the grounds and circumstances of the valuation report, agreed with the client, should be clearly reflected in its content [6]. In particular, the appraiser should receive information from the client (who in most cases will also own the property) regarding whether there are any pending infringement proceedings regarding the construction, or the occupancy (use) of the subject of the valuation, or whether there are grounds for initiating such proceedings. In the case of the contracting party's declaration of lack of knowledge in this regard, the appraiser should make an appropriate mention in the report, and indicate that, according to the contracting party's statement, the building has been constructed and is being used in accordance with applicable regulations. In the event of a different response, the appraiser must inform the contracting party that any non-compliance may affect the price of the property, and include an appropriate mention in the report.

The valuation taking into account the impact of specific irregularities on the final price of the property is possible, however, it seems that correct valuation requires further corrective actions, in particular with the help of experts in the field of architecture and construction.

In a situation where the contracting party is not the owner of the valued property, or there is no knowledge in this respect, or in a situation where the order comes from the court, administrative body or other entity ordering the valuation, due diligence requires the appraiser to request the relevant authorities to provide information on proceedings in relation to the property in question in terms of the correctness of construction, regularity of occupancy (use) and any extraordinary proceedings conducted in relation to the real estate property in question (resumption of provision $145 \mathrm{KPA} /$ Administrative Code, annulment of $156 \mathrm{KPA} /$ Administrative Code). 
Article 155 (3) of the Real Estate Management Act [2] provides for the statutory right of the property appraiser to obtain the information and documents in question. The doctrine emphasizes that the entire enumeration contained in Article 155 section 1 of the Real Estate Management Act, due to the wording "in particular" used by the legislator, it is not exhaustive [7], [8]. Therefore, there should be no doubt that the scope of the information requested cannot be limited to the building permit provision explicitly mentioned in the content, but must also include information about any other extraordinary proceedings regarding this permit or to decisions regarding the occupancy (use) of the valued property. It is also necessary to obtain data from the land and building records in the scope of basic parameters of the valued object (purpose, functional designation, and general technical data). The appraiser should describe what documents he examined and what information he obtained. In accordance with Article 155 [2], real estate estimation uses all necessary and available data on the real estate property.

In the case of receiving a response that there are no pending, present or past proceedings regarding the appraised real estate property and obtaining data from the building register, the appraiser may compare the received data with the data obtained during the actual inspection. The jurisprudence indicates that it would be a failure to exercise due diligence when an expert is aware of the fact that there are repeated divergent entries regarding the condition of the premises in the land and mortgage register and the building directory, or when he fails to undertake measurements of the estimated premises if it is possible to perform such measurements [9].

The view presented in the jurisprudence should also be followed: namely, that due diligence requires that the proper valuation of any real estate property should be preceded by the expert's familiarization with its condition and features. One of the most important features of the building described by the appraiser is its built-up area. If the data in the building directory and in the construction design are divergent, this requires the appraiser to personally verify the area of the estimated building. The above is important because in case it turns out that in reality the building area is larger than one indicated in the construction design, it is obvious that the usable area, total (overall) area, and volume would change. In the event of a discrepancy as to the area of the estimated real estate, the measurements should be carried out by the appraiser, because that would guarantee the firm and correct description of the real estate property, conducted in the manner aimed at its appropriate assessment [10]. Supplementing the above views, it should be pointed out that in case of discrepancies, the appraiser should disclose this circumstance in the content of the appraisal report, along with appropriate reference to this issue [11].

In our opinion, the appraiser is neither entitled nor obliged to determine the reasons for the discrepancies. The expert's duty of special diligence determines the obligation to clearly indicate what data he has based his report on (e.g. actual measurement data) and to clearly indicate any discrepancies.

In the event of obtaining information on on-going proceedings regarding compliance with building regulations, or proceedings regarding the revocation of a final deci- 
sion on a building permit (resumption of proceedings, declaration of invalidity), these circumstances shall not preclude the valuation of the property in question. However, it is necessary to formulate an appropriate reference to the on-going proceedings, and their possible and potential impact on the valuation. For this reason, we do not share the opinion presented in the literature about the need to suspend the valuation until final decisions in this matter have been made [12]. In particular, proceedings for annulment or resumption of proceedings regarding the final decision to grant a building permit are lengthy proceedings. The final decision is subject to appeal to the WSA (Provincial Administrative Court) and the judgment of the WSA is subject to appeal to the NSA (Supreme Administrative Court). Thus, it could be years until the end of such proceedings is reached. Preventing the valuation of such properties would block the operation of the court, the bailiffs or administrative authorities and could be used by interested parties to paralyze the on-going proceedings. In our opinion, obtaining and including in the valuation report the information on the correct occupancy and use of the building, as well as the information regarding possible administrative proceedings and the observed discrepancies between the examined documents and the data obtained during the inspection releases the appraiser from liability for the impact of any non-compliance of the valued object with building regulations on the actual assessment value of that object. The valuation report drawn up with such reservations should be considered correct and made with special diligence appropriate for the professional nature of the appraiser's activity.

In accordance with Article 56 section 3 of the RWN [13], the appraisal should include relevant clauses indicating specific circumstances pertaining to the valuation of the real estate property. One such special circumstance will be the reservation that the indicated amount of the valuation may change due to discrepancies found or proceedings being conducted.

In terms of examining the compliance of the valued real estate property with the relevant provisions of the construction law, it is necessary to mention the requirements imposed on appraisers by banks and other entities verifying the surveys. For example, in practice we come across a clear order to check all required permits and approvals provided for by law (e.g. local spatial development plan, building development decision, decisions regarding building permits, etc.). The necessary attachments to the real estate appraisal report include the documents confirming the adopted technical parameters of the building (such as fragments of architectural and construction documentation/inventory containing, among others, the calculation of the building's area, decision on the occupancy permit/notification of the completion of construction, and commencement of occupancy with the annotation that the competent authority did not raise any objection, and the declaration of use containing information on the technical parameters of the building, building permits or extension permits, as applicable [14]. In practice, it may also be required that the technical and operational parameters adopted for the valuation were verified for compliance with the building permit/construction design in the case of investment projects in the course of implementation, and in the case of completed projects (where the 
occupancy commenced), for their conformity with the facts (subcontracting documentation, survey of the completed building, another document constituting the basis for certificate of premises separation, building permit, or occupancy permit). Further required necessary attachments to the survey include documents confirming the adopted technical parameters of the building in the appraisal report (including fragments of architectural and construction documentation/survey of the completed building, containing, among others, a summary of the building area, decision on the occupancy permit/notification of completion of the construction and commencement of use with annotation that the competent authority did not object, and the declaration of use containing information on the technical parameters of the building [15]. A more general requirement is that the real estate appraiser should quote all circumstances that may increase or decrease the creditor's risk, including those potentially affecting the value of the real estate property being valued, e.g. objects erected in breach of legal regulations. In addition, the appraiser is not to include in the valuation the areas, whose implementation is not allowed by the relevant building regulations. The compliance of the area accepted for the valuation with the occupancy permit (and for real estate in progress - with the construction permit) is required, and any discrepancies should be explained in the report [16]. Other entities oblige the appraiser to fill out a special form pertaining to risk factors, where answers are required in particular to the question whether the buildings; outlines go beyond the plot, and whether the building has been approved for occupancy (put into use) [17].

Based on the analysis of the indicated requirements, it should be pointed out that these institutions aim at shifting the risk associated with "defective" real estate to the real estate property appraiser. A real estate appraisal expert who is a professional and accepts such a wide scope of his duties should be aware of the scope of his responsibility. In the event of damage suffered by the bank, for instance due to the inability to be fully satisfied with the property being the subject of the valuation due to its defects related to the construction process, it is possible to submit appropriate claims for damages against the real estate property appraiser [18] (see, e.g., Judgment SA 2015).

\section{Conclusions}

The issue of the scope of verifying the compliance between the state of the built property and the provisions of the construction law shows discrepancies both in case law and in practice. As a rule, a real estate property appraiser is not authorized to assess whether a given object, in whole or in part, has been built or is being used in accordance with building regulations. The appraiser, due to the statutory duty to exercise special diligence appropriate to the professional nature of his activities, is required to collect and use all necessary and available data on the given real estate property. Such data will include, for example, documents confirming the approval for the occupancy of a given building, data from the land and building records, information on on-going administrative proceedings regarding the real estate property in question, and data obtained directly from the inspection. If a discrepancy is found in the analysed documentation, 
the appraiser should mention it in the report. The appraiser is not entitled or obliged to determine the causes of the discrepancies. The said circumstances justify the inclusion in the report of a clause that the valuation of the property in question may change due to discrepancies or proceedings being conducted. Failure to provide relevant information or reservations may justify the appraiser's liability under the relevant provisions of the Civil Code [19].

\section{References}

[1] Ustawa z dnia 7 lipca 1994 r. - Prawo budowlane, Dz. U. Nr 89, poz. 414 ze zm.

[2] Ustawa o gospodarce nieruchomościami z dnia 21 sierpnia 1997 r., Dz. U. Nr 115, poz. 741 ze zm.

[3] Kodeks postępowania administracyjnego z dnia 14 czerwca 1960 r., Dz. U. Nr 30, poz. 168 ze zm.

[4] Bitner Agnieszka, Statystyka opisowa w wycenie nieruchomości. Część I - wyznaczenie miar zbioru danych. Rzeczoznawca Majątkowy 2013, Nr 1 (77), 18-21.

[5] Bitner Agnieszka, Statystyka opisowa w wycenie nieruchomości. Część II - graficzna prezentacja danych. Rzeczoznawca Majątkowy 2013, Nr 2 (78), 7-14.

[6] Wyrok Sądu Apelacyjnego w Gdańsku - I Wydział Cywilny z dnia 24 września 2015 r. I ACa 332/15. www.orzeczenia.ms.gov.pl, Legalis.

[7] Ustawa o gospodarce nieruchomościami. Komentarz Jacek Jaworski, Arkadiusz Prusaczyk, Adam Tułodziecki, Marian Wolanin 2017. Komentarz do art. 155, Legalis.

[8] Gospodarka nieruchomościami. Komentarz red. dr Dariusz Pęchorzewski, Michał Horoszko 2014, Komentarz do art. 155, Legalis.

[9] Wyrok Sądu Okręgowego w Łodzi z dnia 23 maja 2016 r., sygn akt III Ca 200/16. https:// www.saos.org.pl/judgments/content/239434.html (accessed: 06.08.2019).

[10] Wyrok Wojewódzkiego Sądu Administracyjnego z siedzibą w Lublinie z dnia 15 grudnia 2017 r., I SA/Lu 763/17, Legalis.

[11] Wyrok Naczelnego Sądu Administracyjnego z dnia 29 sierpnia 2017 r., II GSK 3093/15, Legalis.

[12] Dydenko Jerzy (red.), Szacowanie nieruchomości. Rzeczoznawstwo Majątkowe 2015, 220.

[13] Rozporządzenie Rady Ministrów w sprawie wyceny nieruchomości i sporządzania operatu szacunkowego z dnia 21 września 2004 r., Dz. U. Nr 207, poz. 2109 ze zm.

[14] Zasady Oceny Wartości Nieruchomości w Alior Bank SA. Załącznik nr 3. https://www. aliorbank.pl (accessed: 06.08.2019).

[15] Wytyczne dla rzeczoznawców majątkowych w zakresie sporządzania operatu szacunkowego nieruchomości. Załącznik nr 2 do Zasad przejmowania długu podmiotu prowadzącego gospodarstwo rolne przez Krajowy Ośrodek Wsparcia Rolnictwa Wersja 1.0 z dnia 08.02.2019. www.kowr.gov.pl (accessed: 06.08.2019).

[16] Wytyczne dla rzeczoznawców majątkowych w zakresie sporządzania operatu szacunkowego nieruchomości proponowanych na przyjęcie lub stanowiące zabezpieczanie wierzytelności BGK. www.wtbs.pl (accessed: 06.08.2019).

[17] Formularz ryzyk związanych z wycenianą nieruchomości ING Bank Śląski SA. www.ing.pl (accessed: 06.08.2019).

[18] Wyrok Sądu Apelacyjnego w Gdańsku - I Wydział Cywilny z dnia 24 września 2015 r., I ACa 332/15. www.orzeczenia.ms.gov.pl, Legalis.

[19] Ustawa z dnia 23 kwietnia 1964 r. Kodeks Cywilny, Dz. U. Nr 16, poz. 93 ze zm. 
Dr inż. Maria Zbylut-Górska Uniwersytet Rolniczy w Krakowie Katedra Geodezji

30-149 Kraków, ul. Balicka 253a

e-mail: m.zbylut-gorska@urk.edu.pl

ORCID: 0000-0003-4436-8248

Dr Adam Górski, adwokat

30-225, Kraków, al. Panieńskich Skał 2 